\title{
MARINE DEBRIS ACCUMULATION ON THE BEACH IN LIBONG, A SMALL ISLAND IN ANDAMAN SEA, THAILAND
}

\author{
Pradit, S..$^{1,2^{*}}$ - NitiRATSUWAN, T. ${ }^{3}$ - Towatana, P. ${ }^{1,2}$ - JUALAONG, S. ${ }^{4}-$ SoRnPlang, K. ${ }^{1,2}$ \\ NOPPRADIT, P. ${ }^{1,2}$ - JIRAJARUS, M. ${ }^{1,2}-$ DARAKAI, Y. ${ }^{1}$ - WEERAWONG, C. ${ }^{5}$ \\ ${ }^{I}$ Marine and Coastal Resources Institute, Faculty of Environmental Management, Prince of \\ Songkla University, Songkhla 90110, Thailand \\ (phone: +66-74-282-329; fax: +66-74-212-782)
}

${ }^{2}$ Coastal Oceanography and Climate Change Research Center, Prince of Songkla University, Hat Yai, Songkhla 90110, Thailand

${ }^{3}$ Faculty of Science and Fisheries Technology, Trang Campus, Rajamangala University of technology Srivijaya, Tuang 92150, Thailand

${ }^{4}$ Marine and Coastal Resources and Development Center, The Eastern Gulf of Thailand, Department of Marine and Coastal, Rayong Province, Thailand

${ }^{5}$ Mu Ko Libong Non-hunting Area, Department of National Parks, Wildlife and Plant Conservation, Thailand

${ }^{*}$ Corresponding author

e-mail: siriporn.pra@psu.ac.th; phone: +66-74-282-320; fax: +66-74-212-782

(Received $6^{\text {th }}$ Mar 2020; accepted $2^{\text {nd }}$ Jul 2020)

\begin{abstract}
Marine debris is a global issue and a hot topic in Thailand. This study involved collecting and quantifying various types of debris at Libong Island. The study area is Libong Island, a small Island in Andaman Sea, with high biodiversity and an important source of sea grass providing a significant and vital habitat for endangered dugongs. Debris was collected on sandy beach and mud beach areas between May and August 2019. The results indicated that the ceramic and glass debris was found in the greatest number followed by plastic and other debris, thin plastic and hard plastic. The major contributing factor for the debris abundance in Libong beach was the shoreline and recreational activities which showed that the landbased sources provided major inputs of plastic pollution at the beaches. The calculation of the Clean Coastal Index (CCI) of Libong Island yielded a result of 5.8 at the sandy beach whereas at the mud beach was 0.65 . Thus, the sandy beach was classified as moderately clean and the mud beach was classified as very clean. Keywords: marine litter, plastic, mud beach, dugongs, Thailand
\end{abstract}

\section{Introduction}

Marine debris accumulates on virtually all coasts from the poles to the equator (Haynes, 1997; Convey et al., 2002). Marine debris is defined as all solid materials of anthropogenic origin that are discarded at the sea or reach the sea (Rayon-Vina et al., 2018). It can be found on the coast, at the sea surface, on the seabed, and even in remote areas (Ivar do Sul et al., 2009; Hirai et al., 2011; Eriksen et al., 2014). Marine anthropogenic debris or debris is generally defined as "any persistent, manufactured or processed solid material discarded, disposed or abandoned in the marine and coastal environment" (Galgani et al., 2010). Ingestion of marine debris (Tomás et al., 2002; Goldstein and Goodwin, 2013) and entanglement by marine organisms, including turtles and seabirds (Matsuoka et al., 2005), have been reported from various parts of the world. Humans are also affected by marine debris, which contributes heavily to landscape degradation (Somerville et al., 2003; Wyles 
et al., 2015; Sarafraz et al., 2016). Landscape degradation by debris is not only a matter of aesthetics, but also economy (Rayon-Vina et al., 2018). As industrial development has accelerated and the manufacture and disposal of plastics have increased, concerns on plastic pollution are growing (Chae and An, 2018). There is no doubt today that plastic waste generated by the world's populations is accumulating in our seas and oceans at large amounts. Numerous marine species including fishes, seabirds, marine mammals and turtles have been reported to either ingest plastic or get entangled in marine debris (Kühn et al., 2015; Gall and Thompson, 2015). The production of plastics has grown continuously since the 1950s, with an increase of $37 \%$ over the last decade (Plastic Europe, 2016).

At present, plastic pollution is considered as a crucial environmental problem (UNEP, 2014), and it is identified alongside climate change as an emerging issue that might affect human health and biological diversity in the near to medium-term future (Sutherland et al., 2010). Plastic debris and marine wastes are currently important problems of Thailand, ASEAN and the world. Thailand is presently ranked as the world's 6th largest marine waste releasing country and therefore, the problems of plastic waste and marine wastes in the marine and coastal ecosystems are the urgent problems that need to be solved as well as other environmental problems caused by other types of pollution. Marine pollution caused by floating plastics in the sea certainly affects numerous marine species. As those sea creatures eat plastic waste into their bodies or plastic wastes entangle around their bodies, this finally causes their fatal injuries and a huge impact on the marine and coastal ecosystems. For example, it causes the deaths and injuries of rare sea animals such as sea turtles, dolphins and whales, etc. at the rate of 60-70 animals/year. In June 2019, a shortfinned pilot whale died from eating 85 plastic bags at Jana District, Songkhla Province and the source of marine waste released by the main activities of communities on the shore related to landfills, piers, beach tourism, transportation, fishery, etc. Therefore, the management of municipal waste is likely to face the problem regarding the increase in amount of municipal waste due to the inadequate reduction of amount of waste caused by no efficiency in debris separation at the beginning as well as lack of complete operation of waste management including luxury plastic bag consumption.

Islands, especially the tropical and subtropical zones, are hotspots of biodiversity, hosting diverse ecosystems such as seagrass beds, mangroves and coral reefs (Nurse et al., 2001; de Scisciolo et al., 2016). At the same time, islands are one of the most vulnerable environments on Earth and a diversity of processes severely threaten them. These processes include climate change (Campbell and Barnett, 2010), sea level rise (Leatherman and Beller-Simms, 1997; Williams et al., 2018), unsustainable use of local resources (UNEP, 2009), overpopulation (Rangel-Buitrago et al., 2018), and marine debris (Bergmann and Gutow, 2015; Lavers and Bond, 2017; Lavers et al., 2019; Williams and Rangel-Buitrago, 2019). The study area of this study is Libong Island, Trang Province, which is an island with high biodiversity and an important source of sea grass providing a significant habitat of endangered dugongs. It is currently encountering waste management problems since most islanders get rid of their debris by dumping some of the waste directly into the sea. This has certainly affected marine animals such as the dugongs eating sea waste resulting in blocking movement of food in their intestines and finally causing the death, etc. It can be obviously seen that the problem of marine wastes has a serious adverse impact on the environmental integrity and living organisms including human food security as well. Therefore, the objective of this investigation was to study the types and amounts of marine waste in the sand and mud beach ecosystems of Libong Island which was the first study of recording the waste type separation data showing the amount of each type of 
marine wastes found. This definitely provides valuable information for finding suitable ways to manage marine debris for this small island that has the high potential to support tourist activities in the future.

\section{Materials and methods}

\section{Study area}

Libong Island is located at latitude $07^{\circ} 14^{\prime}-07^{\circ} 17^{\prime} \mathrm{N}$ and longitude $99^{\circ} 22^{\prime}-09^{\circ} 27^{\prime} \mathrm{E}$ on the western coastline of Kantang District, Trang Province, and approximately $2-3 \mathrm{~km}$ away from the mainland (Fig. 1). Libong Island has a diverse ecosystem, including coral reefs, mangrove forests and extensive seagrass beds. The study site is situated on the east coast of the island where the large seagrass bed and mud flat can be found.at a depth between 0.5-2.8 $\mathrm{m}$ above sea level (Wirachwong and Holmer, 2010). Libong Island is also important ecological area because it is the significant and vital habitat of the endangered dugongs in Trang Province (Adulyanukosol and Thongsukdee, 2006). Libong islanders presently earn their living by fishing and gardening. The villages located on the island of Libong consist of 4 villages, which are Ban Sai Kaew (Village No. 7), Ban Batu Poo Tae (Village No. 4), Ban Lang Khao (Village No. 5) and Ban Kok Sa Ton (Village No. 1), Libong Island Subdistrict with a total population of 717 people. The research area was Village No. 7 with both mud and sandy beach ecosystems. Our investigation is the first study regarding the waste contamination on the Libong Island. This beach was the best choice for being selected since it is the largest area of sea grass in the island of Libong. This sea grass source is biodiversity importance as well as a food source for dugongs. Thus, its ecological system is very delicate and sensitive to marin waste pollution. Moreover the mud beach area is a buffer zone between the sandy beach and the sea grass area.
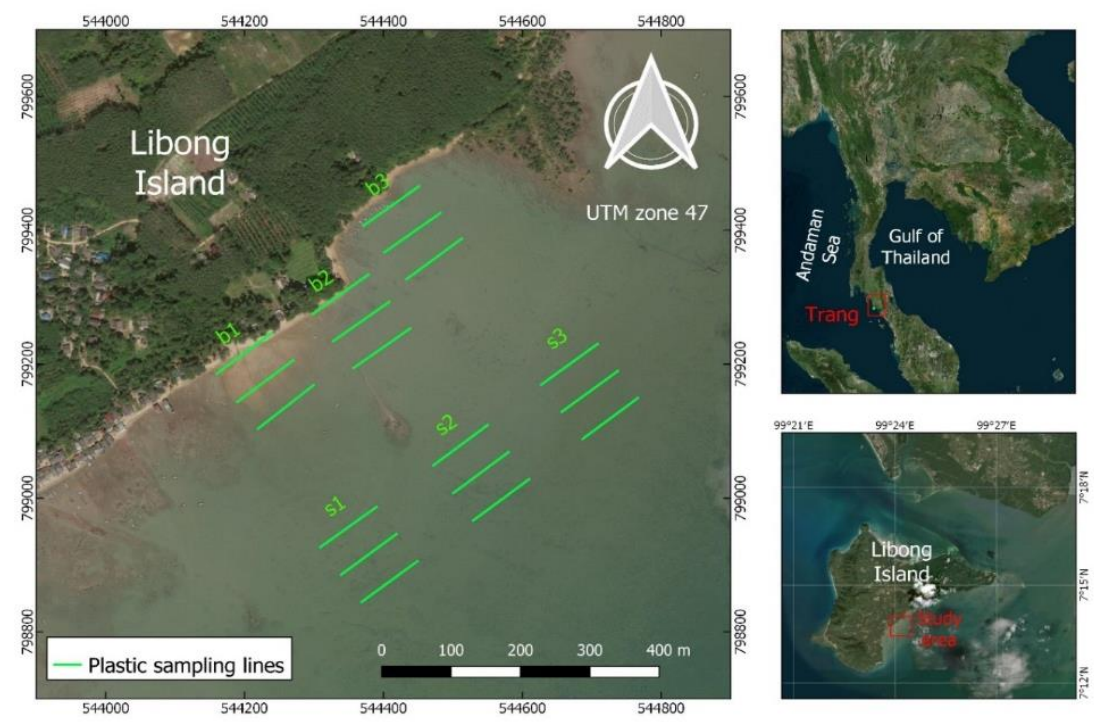

Figure 1. Marine debris sampling areas at Village No. 7, Libong Island Subdistrict, Kantang District, Trang Province. The sandy beach sampling area included bl (beachhead) with a residential area, $b 2$ (the middle of the beach) possessing vacant land and b3 (the end of the

beach) with a residential area mixed with a small pier and a few boats. The mud beach sampling area was composed of 3 sites: $s 1$ (beachhead), $s 2$ (the middle of the beach) and s3 (the end of the beach) 


\section{Survey method}

Our study on marine and plastic waste type in 2 ecosystems (sandy and mud beaches) was conducted by surveying and classifying marine waste according to the UNEP / IOC Guideline on Survey and Monitoring of Marine Litter (Cheshire and Adler, 2009). Then, the collected data from the UNEP / IOC method was converted and transferred into a record form of International Coastal Cleanup (ICC, 2009) which was classified marine waste by activity. Marine debris investigation was conducted by collecting marine debris samples 1 time per month at Village No. 7, Libong Island Subdistrict, Kantang District, Trang Province, between May - August 2019. This sample collection represented the samples ofrainy season (May - October) underthe southwest monsooninfluence. The monsoon wind blowstoward the sampling area and therefore during this time tide and wind will certainlyblow more waste into the study area thanthat of other seasons. There were 6 sampling sites consisting of 3 sites of sandy and rocky beaches which were b1 (beachhead) with a residential area, b2 (the middle of the beach) possessing vacant land and $b 3$ (the end of the beach) with a residential area mixed with a small pier and a few boats. The rest was composed of 3 sites of the mud beach: $\mathrm{s} 1$ (beachhead), s2 (the middle of the beach) and s3 (the end of the beach). Each debris sampling area covered $100 \times 100 \mathrm{~m}$ (consisting of 3 transects with $100 \mathrm{~m}$ long for each transect). Walking along the transect and collecting all the visible debris were conducted. The collected debris was brought back, separated and weighted according to their types.

\section{Classification and quantification}

This study divided the marine debris into 6 types which were hard plastic, thin plastic, fabric and fiber, polymer compound, glass and ceramics and others (foam, steel, metal, paper, wood, etc.). Furthermore, debris released from various activities was divided into 5 broad categories of origin as follows: 1) Shoreline and recreational activities discarded the debris from communities or tourists. 2) Fishing activities and sailing released the debris from various types of vessels and fishing equipment. 3) Medical equipment released the debris related to sanitary and medical waste. 4) Large size debris was abandoned as electrical appliance waste, construction materials, furniture and car equipment. 5) Other debris was debris that could not be specified the type of activities that generated the debris.

Calculation of the Clean Coastal Index (CCI) was done for assessing the cleanliness level of the coast (Alkalay et al., 2007). It was employed as a tool for evaluation of the "Clean Coastal" program that took place in Israel. According to Alkalay et al. (2007), this index was calculated using the formula below, with coefficient $\mathrm{K}$ (value $=20$ ) inserted into the equation for statistical and convenient reasons. The index only took plastic items into account. The result corresponded to the beach CCI rank as: "very clean", 0-2; "clean", 2-5; "moderate", 5-10; "dirty", 10-20; or "extremely dirty", 20 and higher.

$$
\mathrm{CCI}=((\text { Total number of plastic parts }) /(\text { Sampled area })) \times \mathrm{K}
$$

It was important to notice that this method only regarded plastic items with a size greater than $2 \mathrm{~cm}$ (Marin et al., 2019). Thus, for this study, all items greater than $2 \mathrm{~cm}$ were recorded.

The statistical analysis was used to calculate the minimum, maximum, average and standard deviation by excel program. 


\section{Results and discussion}

\section{Quantity of marine debris}

The survey of marine debris samples between May and August 2019 found a total of 1,400 pieces of marine debris in the study from all the stations (Fig. 2). In June, the largest number of debris found was 579 pieces, followed by 509, 191 and 121 pieces of debris were found in May, July and August, respectively. The total weight of the debris from all the stations from May to August 2019 was $53.4 \mathrm{~kg}$. In May, the highest weight of debris was $27.1 \mathrm{~kg}$, followed by 16.3, 6.2, $3.8 \mathrm{~kg}$ were found in June, August and July respectively since May was the first month of sampling and therefore resulting in a large amount of debris was collected. Collecting debris every month consecutively was carried out and caused the amount of debris to gradually decrease, such as in July and August, the amount and weight of debris found less than half of the amount and weight of debris in May. Moreover, the amounts of all the types of debris found in the sandy beach in each month were much higher than those of the mud beach (Table 1) and therefore, the sandy and rock beaches were much more dirty than the mud beach. It may be because the sandy and rock beaches are close to the highest tide line and receive the waste from the community nearby and therefore causing more accumulation of debris than that of the other areas located offshore.

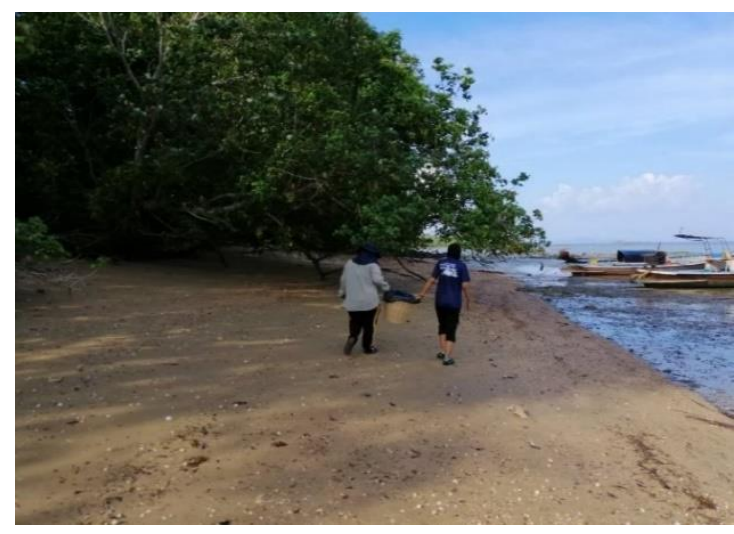

(a)

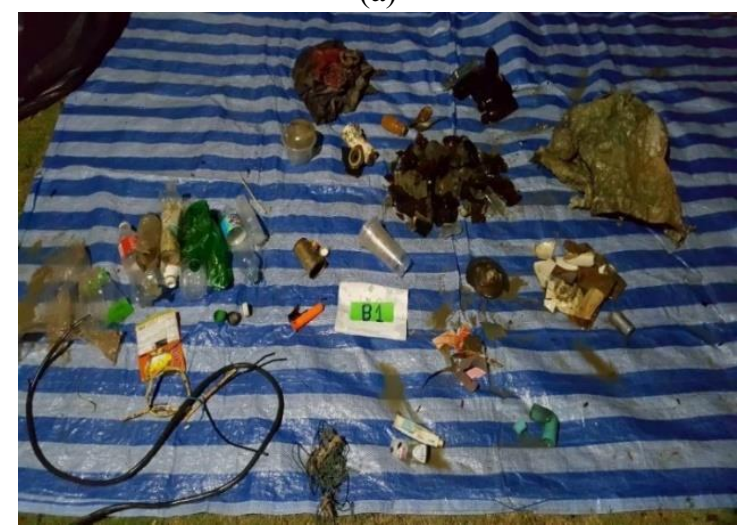

(c)

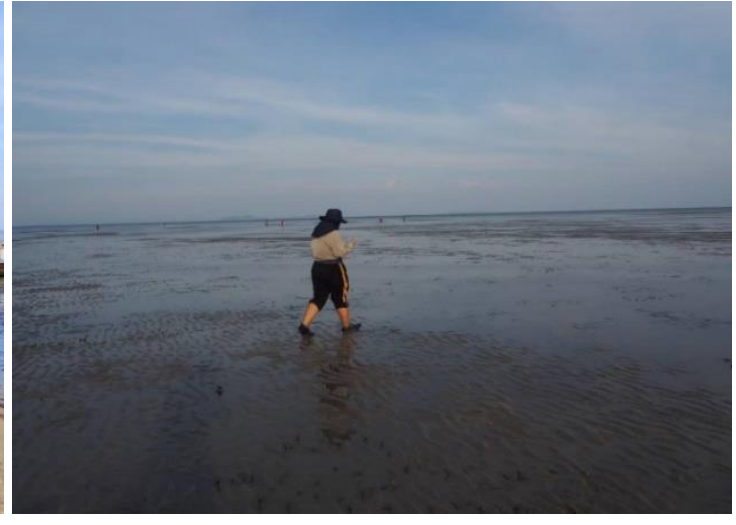

(b)

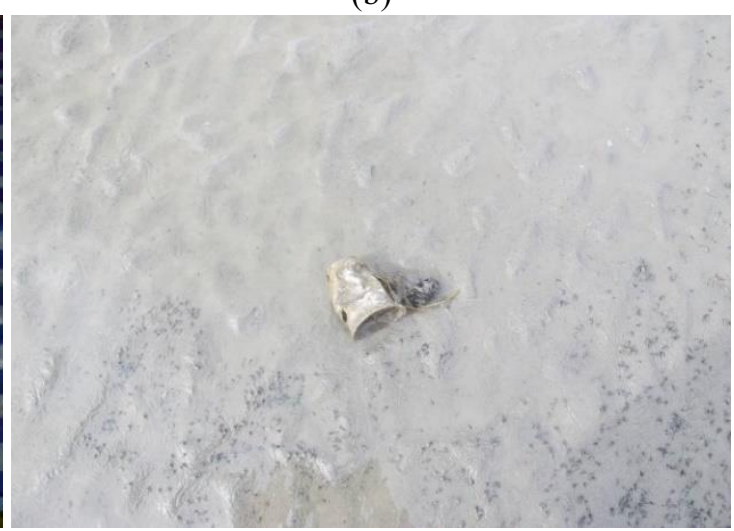

(d)

Figure 2. Collecting marine debris samples on (a) sandy beach (b) mud beach; Samples of marine debris found at Libong Island (c) debris from staion b1 (beachhead) with a residential area and $(d)$ plastic glass found on mud beach 
Table 1. Abundance and weight of debris collected on Libong Island from May-August 2019

\begin{tabular}{|c|c|c|c|c|c|c|c|}
\hline \multirow[b]{2}{*}{ Sampling location/month } & \multicolumn{7}{|c|}{ Debris type } \\
\hline & $\begin{array}{l}\text { Plastic } \\
\text { (hard) }\end{array}$ & $\begin{array}{c}\text { Plastic } \\
\text { (soft/thin) }\end{array}$ & \begin{tabular}{|l|} 
Fabric \\
or fiber
\end{tabular} & $\begin{array}{c}\text { Polymer } \\
\text { compounds }\end{array}$ & \begin{tabular}{|l|} 
Glass or \\
ceramic
\end{tabular} & Other & Total \\
\hline \multicolumn{8}{|l|}{ A. Sandy beach } \\
\hline \multicolumn{8}{|l|}{ a. Number of debris (piece) } \\
\hline May 2019 & 58 & 28 & 10 & 0 & 313 & 75 & 484 \\
\hline June 2019 & 77 & 107 & 24 & 4 & 254 & 113 & 579 \\
\hline July 2019 & 18 & 18 & 2 & 2 & 64 & 44 & 148 \\
\hline Aug 2019 & 21 & 23 & 6 & 3 & 38 & 30 & 121 \\
\hline Total & 174 & 176 & 42 & 9 & 669 & 262 & 1332 \\
\hline Average & 43.50 & 44 & 10.50 & 2.25 & 167.25 & 65.5 & 333 \\
\hline SD & 28.80 & 42.20 & 9.57 & 1.71 & 136.79 & 36.83 & 255.90 \\
\hline \multicolumn{8}{|l|}{ b. Weight of debris $(\mathrm{kg})$} \\
\hline May 2019 & 1.51 & 0.42 & 1.64 & 0.00 & 7.61 & 6.68 & 17.86 \\
\hline June 2019 & 1.33 & 1.17 & 1.70 & 0.38 & 6.58 & 5.11 & 16.27 \\
\hline July 2019 & 0.01 & 0.01 & 0.01 & 0.00 & 1.01 & 2.75 & 3.78 \\
\hline Aug 2019 & 0.33 & 0.27 & 2.03 & 0.29 & 1.46 & 1.79 & 6.18 \\
\hline Total & 3.18 & 1.87 & 5.38 & 0.67 & 16.66 & 16.33 & 44.08 \\
\hline Average & 0.79 & 0.47 & 1.35 & 0.17 & 4.17 & 4.08 & 11.02 \\
\hline SD & 0.74 & 0.50 & 0.91 & 0.20 & 3.42 & 2.22 & 7.98 \\
\hline \multicolumn{8}{|l|}{ B. Mud beach } \\
\hline \multicolumn{8}{|l|}{ a. Number of debris (piece) } \\
\hline May 2019 & 0 & 6 & 0 & 0 & 0 & 19 & 25 \\
\hline June 2019 & 0 & 0 & 0 & 0 & 0 & 0 & 0 \\
\hline July 2019 & 8 & 25 & 1 & 0 & 3 & 6 & 43 \\
\hline Aug 2019 & 0 & 0 & 0 & 0 & 0 & 0 & 0 \\
\hline Total & 8 & 31 & 1 & 0 & 3 & 25 & 68 \\
\hline Average & 2 & 7.75 & 0.25 & 0 & 0.75 & 6.25 & 17 \\
\hline $\mathrm{SD}$ & 4 & 11.84 & 0.50 & 0 & 1.50 & 8.96 & 26.80 \\
\hline \multicolumn{8}{|l|}{ b. Weight of debris $(\mathrm{kg})$} \\
\hline May 2019 & 0.00 & 0.24 & 0.00 & 0.00 & 0.00 & 9.00 & 9.24 \\
\hline June 2019 & 0.00 & 0.00 & 0.00 & 0.00 & 0.00 & 0.00 & 0.00 \\
\hline July 2019 & 0.01 & 0.00 & 0.00 & 0.00 & 0.00 & 0.00 & 0.02 \\
\hline Aug 2019 & 0.00 & 0.00 & 0.00 & 0.00 & 0.00 & 0.00 & 0.00 \\
\hline Total & 0.01 & 0.24 & 0.00 & 0.00 & 0.00 & 9.00 & 9.26 \\
\hline Average & 0.00 & 0.06 & 0.00 & 0.00 & 0.00 & 2.25 & 2.32 \\
\hline $\mathrm{SD}$ & 0.01 & 0.12 & 0.00 & 0.00 & 0.00 & 4.50 & 4.63 \\
\hline
\end{tabular}

Remark: $\mathrm{SD}=$ Standard deviation

May was the first waste collection month. From the obtained data of villager interview, there was no waste collection in the study area before. Hence, the amount of the collected marine waste in May was the accumulate amount of waste before our study. The highest amount of glass waste on the sandy beach in May was observed and decreased in the following months whereas the reverse was true for plastic waste. It might be possible that the waste was transported by sea due to the influence of the southwest monsoon or the 
wind blew plastic waste from the community to accumulate on the beach. Therefore the amount of waste on the beach in June was greater than that in May.

The high amount of glass and ceramic types found in the sandy beach monthly gave the high average quantities of the collected glass and ceramic debris with the high standard deviation as compared to other types of debris (Table 1) since the amounts of glass and ceram found varied quite a lot among each month (May to August 2019). Furthermore, the average number of soft/thin plastic debris found in the mud beach was highest as compared to the other debris types (Table 1). This implied that soft/thin plastics probably had some potential to accumulate in the mudflat and could be harmful to the marine organism in this area.

The calculation of the Clean Coastal Index (CCI) of Libong Island was 5.8 at sandy beach whereas at mud beach was 0.65 . Hence, the sandy beach was classified as moderate clean and the mud beach was classified as very clean. However, it probably depends on the season since Libong Island is affected by both Southwest monsoon and Northeast monsoon.

From Table 1, collecting waste samples was carried out 1-2 days every month during the study. This might not be representative amount of the month. However, Libong island beach is relatively clean and still natural with less population and tourist activities. Therefore, it was expected that the collected waste was accumulated for many days. For this research, only one beach sample was collected at Libong Island. The area next to the beach is the mud beach and the largest sea grass area of Libong Island with conservation area for dugong habitat and no residential area.

\section{Types of marine debris}

The survey found that the collection of marine debris samples on both the sand and mud beaches between May and August 2019, the most common types of debris were glass and ceramics $=672$ pieces, weight $24.7 \mathrm{~kg}$, followed by other debris $=287$ pieces, weight $25.3 \mathrm{~kg}$, thin plastic $=207$ pieces, weight $2.1 \mathrm{~kg}$, hard plastic $=182$ pieces, weight $3.2 \mathrm{~kg}$, fabric and fiber $=42$ pieces, weight $5.4 \mathrm{~kg}$ and polymer compound $=10$ pieces, weight $0.7 \mathrm{~kg}$, which was contrary to the study results of Khananurux (2012). She studied the amount of each type of marine debris per area of Bangsaen Beach, Chonburi Province and found that plastic debris had the highest amount of $34.60 \pm 16.03$ pieces/ $100 \mathrm{~m}^{2}$, followed by cigarette / cigarette butt $=7.84 \pm 5.67$ pieces $/ 100 \mathrm{~m}^{2}$ and rubber $=6.74 \pm 3.78$ pieces $/ 100 \mathrm{~m}^{2}$. This was due to the different characteristics of beach area utilization. Bang Saen Beach is utilized in the form of tourist attractions and beach activities. Most of the debris at Bang Saen Beach is caused by tourists but the sampling areas of Libong Island are not a tourist attraction and have communities located nearby the beach. There is a pier for small fishing boats in front of the beach and one homestay located at study area. The study at Rajamangala Beach located at the mainland of Trang Province showed that the total of marine debris found was 296 pieces, total weight 10,433 g consisting of styrofoam $(51.35 \%)$, hard plastic (16.89\%) and fiber and fabric (29.89\%) (Thammavichan et al., 2014). The number of pieces was concordant with our study since Libong Island like Trang Province was affected by monsoon wind. Thus, the debris found on beach was probably released from the communities or influenced by the southwest monsoon during May to October.

The amounts of debris found of each sampling area in sand and rock areas at b1, b2 and b3 and mud beach areas at s1, s2 and s3 classified by the type of debris (Figs. 3-4) were as follows. 


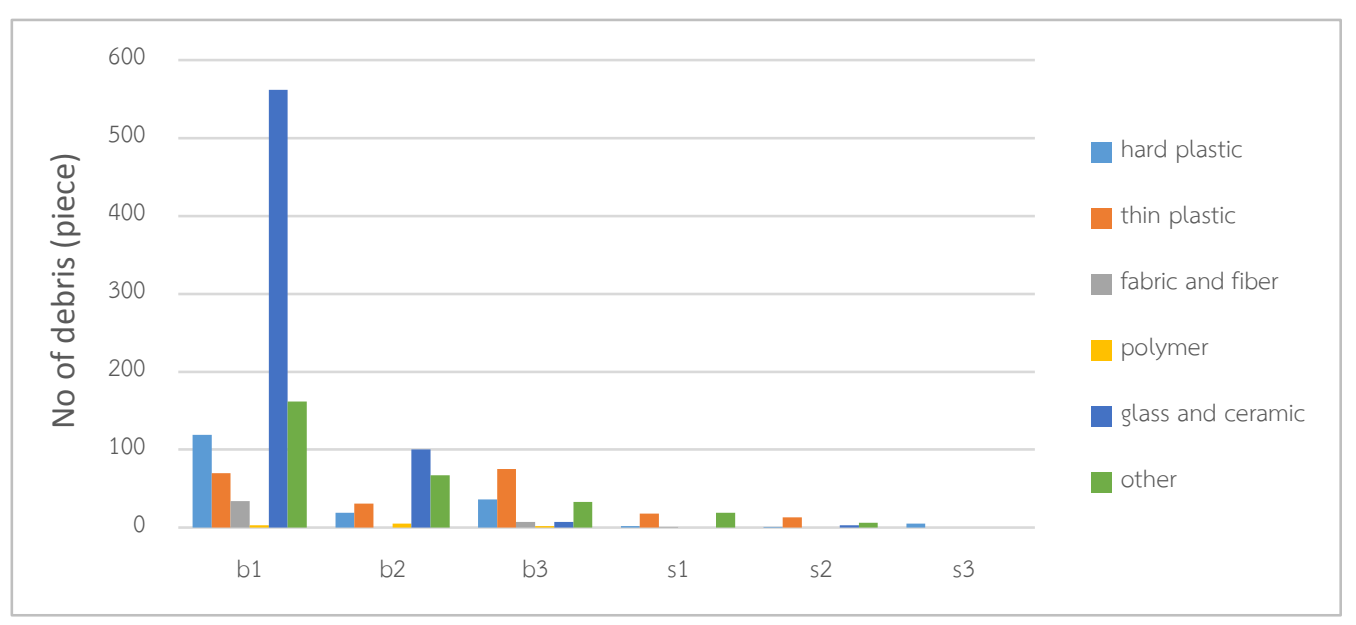

Figure 3. The amount of marine debris (pieces) in each sampling area classified by debris types between May - August 2019. The sandy beach sampling area included b1 (beachhead) with a residential area, $b 2$ (the middle of the beach) possessing vacant land and $b 3$ (the end of the

beach) with a residential area mixed with a small pier and a few boats. The mud beach sampling area was composed of 3 sites of the mud beach: s1 (beachhead), s2 (the middle of the beach) and 33 (the end of the beach)

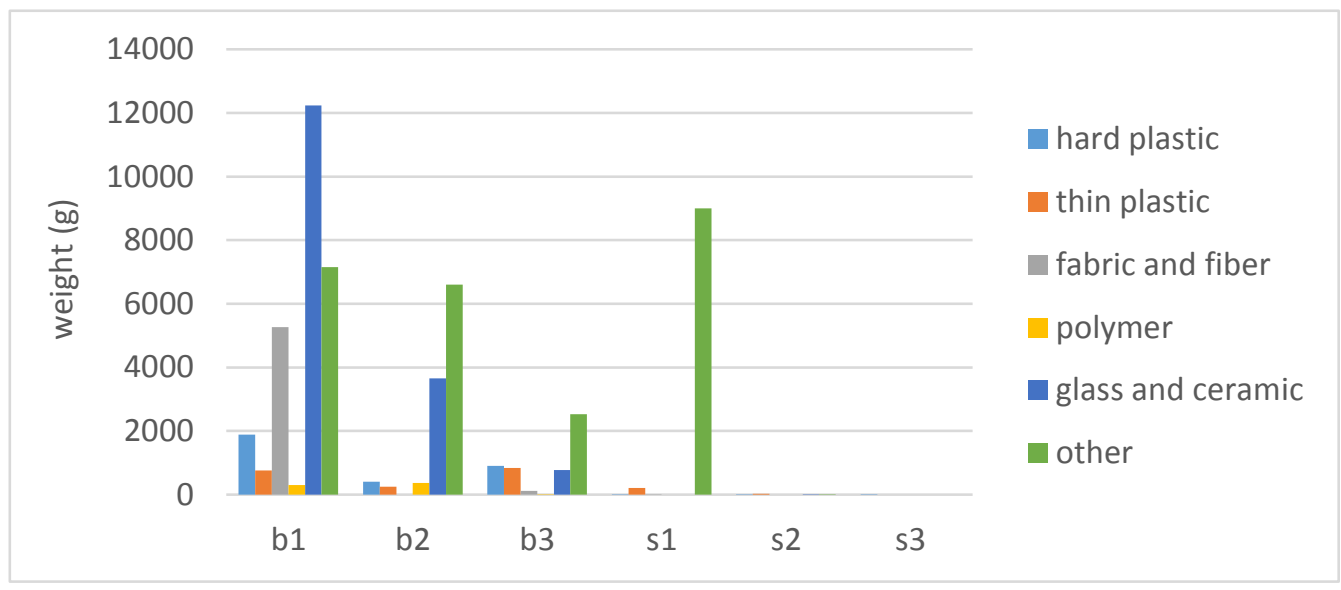

Figure 4. The weight of marine debris (grams) in each sampling area classified by debris types between May - August 2019. The sandy beach sampling area included b1 (beachhead) with a residential area, $b 2$ (the middle of the beach) possessing vacant land and $b 3$ (the end of the

beach) with a residential area mixed with a small pier and a few boats. The mud beach sampling area was composed of 3 sites of the mud beach: $s 1$ (beachhead), s2 (the middle of the beach) and 33 (the end of the beach)

1) Sand and rock beach floors at b1 area had the highest amount of glass and ceramic waste $=562$ pieces, weight $12.2 \mathrm{~kg}$ followed by the other debris $=162$ pieces, weight $7.1 \mathrm{~kg}$ and hard plastic $=119$ pieces, weight $1.8 \mathrm{~kg}$. For the $\mathrm{b} 2$ area, the most type found was glass and ceramics $=100$ pieces, weight $3.7 \mathrm{~kg}$, followed by other debris $=67$ pieces, weight $6.6 \mathrm{~kg}$ and thin plastic $=31$ pieces, weight $0.3 \mathrm{~kg}$. The $\mathrm{b} 3$ area, the most commonly found type was the thin plastic $=75$ pieces, weight $0.8 \mathrm{~kg}$ followed by the hard plastic $=36$ pieces, weight $0.9 \mathrm{~kg}$ and other debris $=33$ pieces, weight $2.5 \mathrm{~kg}$. 
2) Mud beach area at $\mathrm{s} 1$ area possessed the largest amount of other debris $=19$ pieces, weight $9 \mathrm{~kg}$, followed by the thin plastic $=18$ pieces, weight $0.2 \mathrm{~kg}$ and the hard plastic $=2$ pieces, weight $0.01 \mathrm{~kg}$ whereas the s2 area, the most type found was the thin plastic $=13$ pieces, weight $0.03 \mathrm{~kg}$ followed by the other debris $=6$ pieces, weight $0.01 \mathrm{~kg}$. For the s3 area, 5 pieces of hard plastic with the weight of $1 \mathrm{~kg}$ were found.

The plastic debris abundance on Libong Island beach was shown in Table 2. The most occurrence was plastic bag $(25.96 \%)$, followed by bottle and tumbler $(15.68 \%)$ and food wrapper $(12.85 \%)$. Moreover, thin plastic was found at the mud station, whereas hard plastic was absent. It probably implied that the lighter debris such as pieces of plastic bags could travel longer distance from shore than that of the hard ones with more weight. Many studies (e.g. Galgani et al., 2000; Hess et al., 1999) report plastic as the major debris collected from coastal zones. On most beaches, plastic items corresponded to over $80 \%$ of the total items collected. Particularly, plastic debris on beaches can be easily fragmented yielding a large amount of microplastics that cannot be collected and can pose significant threats to the marine environment (Andrady, 2017; Song et al., 2017).

Table 2. Plastic debris composition on beach at Libong Island from May-August 2019

\begin{tabular}{c|c|c|c}
\hline No & Plastic debris type & Number (piece) & Occurrence \% \\
\hline 1 & Bottle and tumbler & 61 & 15.68 \\
2 & Cups and dish & 21 & 5.40 \\
3 & Spoon and fork & 4 & 1.03 \\
4 & Container & 13 & 3.34 \\
5 & Bottle cap & 12 & 3.08 \\
6 & Straw & 101 & 1.54 \\
7 & Plastic bag & 50 & 25.96 \\
8 & Food wrapper & 4 & 12.85 \\
9 & Toothpaste tube and toothbrush & 117 & 1.03 \\
10 & Other & 389 & 30.08 \\
\hline Total & & & 100.00 \\
\hline
\end{tabular}

\section{The amount of marine debris classified by sources of activity}

The survey showed the collection of marine debris samples between May and August 2019 as follows: The debris from shoreline and recreational activities was found the most amount of 1,185 pieces, weight $30.7 \mathrm{~kg}$ followed by fishing and sailing activities $=32$ pieces, weight $11.8 \mathrm{~kg}$, large size debris $=164$ pieces, weight $10.5 \mathrm{~kg}$, other debris $=17$ pieces, weight $0.4 \mathrm{~kg}$ and sanitary and medical debris $=2$ pieces, weight $0.06 \mathrm{~kg}$ (Fig. 5 and Fig. 6), which was consistent with the study results of Thamwichan et al. (2014). They found that the marine debris at the Rajamangala Beach, Trang Province and Tung Khen Bay, Phuket Province was mostly generated by shoreline and recreational activities by more than 50 percent followed by fishing and sailing activities 30 percent. That most debris came from land activities which was abandoned and blown to a river and then flown along the water path into the sea. The rest came from coastal activities related to various types of boats such as fishing boats, cargo vessels, piers, fishing, etc.

From the survey of the amounts and types of marine debris in each month, it was found that the sampling area that received the most debris was b1 (beachhead) at the sand and rock beach since there were communities nearby with a pier for small fishing boats in 
front of the beach. The activities that caused the most amount of debris were shoreline and recreational activities. This was probably caused by most debris coming from neighboring communities and the influence of the passing southwest monsoon wind. This corresponded to the sampling area of s1 (beachhead) at the mud beach where most debris from shoreline and recreational activities was found. This study found that the most activities generating debris were certainly caused by shoreline and recreational activities which was well agreed with the previous study of Kumar et al. (2016).

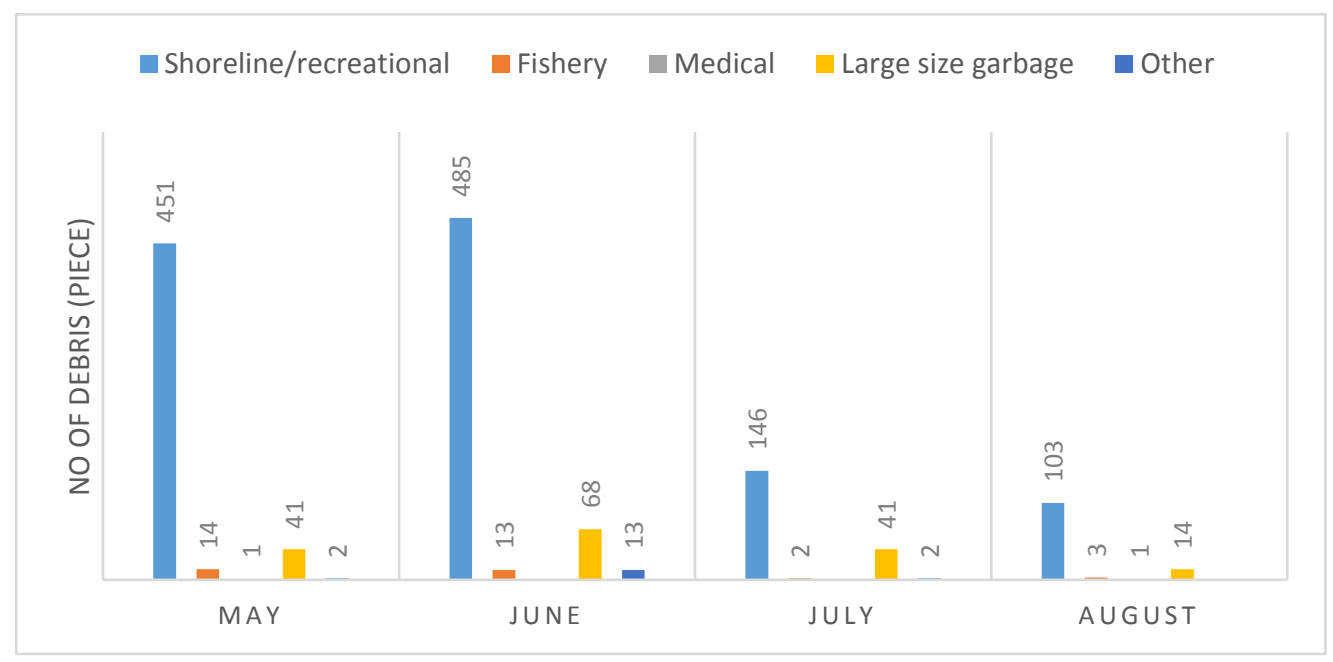

Figure 5. The amount of marine debris (pieces) classified by debris-generating activities between May - August 2019

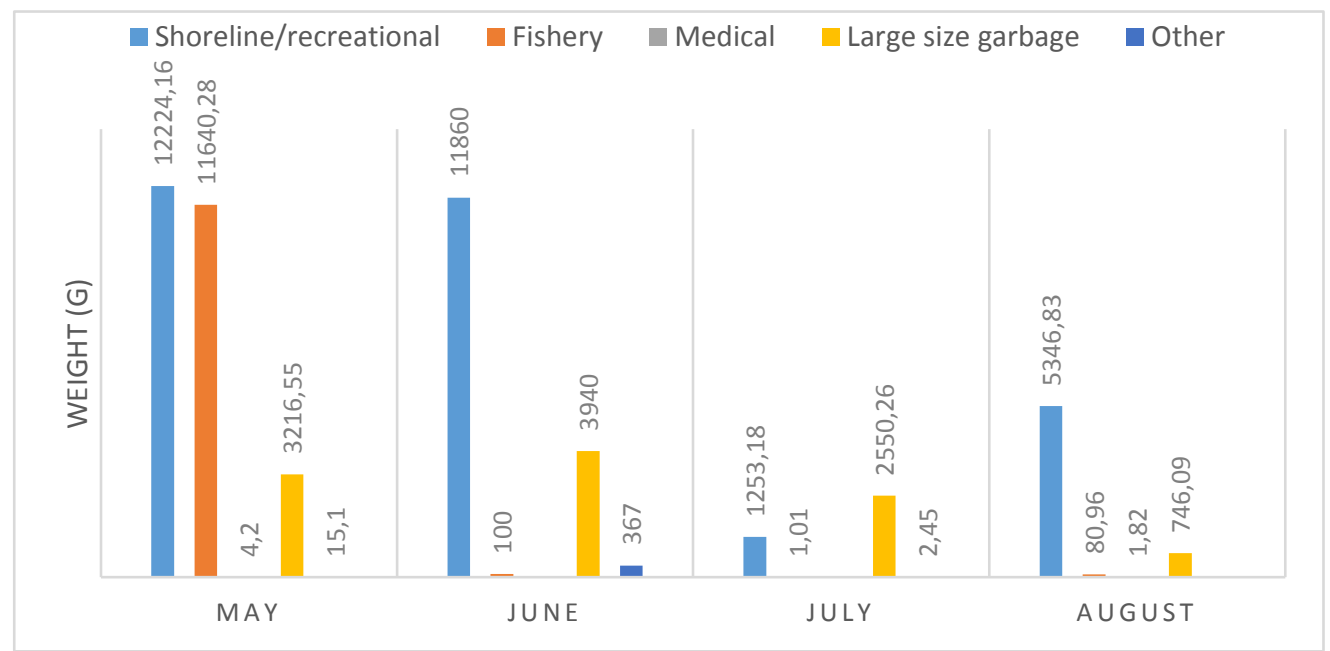

Figure 6. The weight of marine debris ( $g$ ) classified by debris-generating activities between May - August 2019

\section{The amount of marine debris classified by sources of habitat}

The amounts of debris in each sampling area at the sand and rock beach areas namely b1, b2 and b3, and the mud beach areas namely s1, s2 and s3 based on the classification of debris-generating activities were found as follows: 


\section{1) Sand and rock beach}

Debris was mostly found in the area of b1 approximately 950 pieces, weight $27.6 \mathrm{~kg}$, which was the most debris from shoreline and recreational activities ( 808 pieces, weight $19.8 \mathrm{~kg}$ ), followed by large size waste (110 pieces, weight $5.1 \mathrm{~kg})$ and fishing and sailing activities (amount 20 pieces, weight $2.3 \mathrm{~kg}$ ), followed by b2 area, 222 pieces, weight $11.3 \mathrm{~kg}$. The debris of $\mathrm{b} 2$ consisted of the debris released from shoreline and recreational activities (172 pieces, weight $5.9 \mathrm{~kg}$ ), followed by large size debris (43 pieces, weight $4.9 \mathrm{~kg}$ ) and other debris (4 pieces, weight $0.04 \mathrm{~kg}$ ). For the total debris of b3 found was 160 pieces, weight $5.2 \mathrm{~kg}$, which were the most debris generated from shoreline and recreational activities (144 pieces, weight $4.6 \mathrm{~kg}$ ), followed by large size debris ( 8 pieces, weight $0.5 \mathrm{~kg}$ ) and the debris from the activities of fishing and sailing ( 7 pieces, weight $0.1 \mathrm{~kg})$.

2) Mud beach

The s1 area had the most amount of debris found (40 pieces, weight $9.2 \mathrm{~kg}$ ) consisting of the most amount of debris from shoreline and recreational activities (38 pieces, weight $0.3 \mathrm{~kg}$ ), followed by fishing and sailing activities (2 pieces, weight $8.9 \mathrm{~kg}$ ). For the s2 area possessed the total amount of 23 pieces, weight $0.45 \mathrm{~kg}$ that consisted of the most debris generated from shoreline and recreational activities (19 pieces, weight $0.05 \mathrm{~kg}$ ) followed by large size debris ( 3 pieces, weight $0.03 \mathrm{~kg}$ ) and other debris (1 piece, weight $0.01 \mathrm{~kg}$ ). The total amount of debris found at the $\mathrm{s} 3$ area was 5 pieces, weight $0.01 \mathrm{~kg}$, which were mostly generated from shoreline and recreational activities (4 pieces, weight $0.07 \mathrm{~kg}$ ), followed by fishing and sailing activities ( 1 piece, weight $0.04 \mathrm{~kg}$ ).

The above study results were consistent with the study results of Kaikaew et al. (2017). They found the distribution of plastic debris at Tha Wang Beach by collecting samples along a perpendicular line transecting along the coast starting from the highest tide line down to the sea with a length of $50 \mathrm{~m}$. Therefore, the nature of the accumulation of debris with high amount at the beginning of the line transect and gradually reduced to the end which was attributed to the nature of the surveyed area with almost entirely rocky area. The current normally carries plastic debris into rock beach during the high tide and the debris will be trapped during the low tide. The characteristics of the aforementioned study area was similar to the Libong Island sampling areas having a sandy beach with about 10$20 \mathrm{~m}$ long (from the highest sea level) and next to it was rock and mud beaches. Thus, it caused more debris in the sampling areas of sand and rock beaches (b1, b2 and b3) than that of the mud beach (s1, s2 and s3). Apart from that the spatial distribution of marine debris depends on the density differences of the materials, as lighter ones will be transported further (Ryan et al., 2009). Thus, the removal of large-sized plastic debris from coastal areas is the most practical approach to reduce the accumulation of debris including microplastics (Lee et al., 2019).

\section{Conclusion}

From the collection of marine waste 4 times between May - August 2019 in the area of the sand and mud beaches revealed that the most common found wastes were ceramic and glass debrises, followed by plastics mostly consisting of the plastic bags. The marine wastes found in our invetigation came from coastal and recreational activities. However, further research is needed to identify the sources of the wastes whether they came from the communities on the island of Libong or were transported by currents from the coast of Trang Province or waves from the sea. 
The data obtained from this study can help to indicate material types of marine debris in Libong Island. The result showed that the beaches of Libong Island were still fairly clean and had not much plastic debris accumulation as compared to other areas. Regular monitoring of marine debris are suggested since Libong Island is a hotspot of biodiversity as well as vital and important habitat of endanger species, dugongs.

From the research, it was concluded that Libong Island is a small island with agricultural communities on the island. It has sandy and mud beach ecological systems and seagrass that is still natural. The research team proposed the suggestion regarding the marine waste management by increasing the waste collection area to cover the remaining beaches of the island especially the beaches with no community since a lot of plastic wastes were found during May - October. They were probably transported by the influence of the southwest monsoon. The people responsible for implementing waste management activities should consist of the personnel of Libong Island Non-Hunting Area providing waste management plan and budget, the Libong Island School supporting labor and Libong Island Subdistrict Administrative Organization supporting the tools (waste handling equipment). Research groups from Prince of Songkla University and Rajamangala University of Technology Srivijaya, Trang Campus had research knowledge on Libong Island waste management and a role to coordinate among government and private organizations. They proposed the use of various technologies and participate in surveying, collecting, classifying waste and inventing new products from the wastes (innovation) of the Libong Island area.

Acknowledgments. This work was financially supported by by Grand Challenges Thailand: Thai Ocean Waste Free, National Research Council of Thailand (Sub project: Marine litter and microplastic at Libong Island, Trang Province). We would like to express our sincere appreciation to the Department of National Parks, Wildlife and Plant Conservation for allowing us to conduct the research at Libong Island. We owe many thanks to reviewers for assisting us to complete the manuscript.

\section{REFERENCES}

[1] Adulyanukosol, K., Thongsukdee, S. (2006): Dugong Survey at Muk-Talibong Islands, Trang Province. - Marine and Coastal Resources Research \& Development Institute, Bangkok.

[2] Alkalay, R., Pasternak, G., Zask, A. (2007): Clean-coast index-A new approach for beach cleanliness assessment. - Ocean \& Coastal Management 50: 352-362.

[3] Andrady, A. L. (2017): The plastic in microplastics: A review. - Marine Pollution Bulletin 119: 12-22.

[4] Bergmann, M., Gutow, L., Klages, M. (2015): Marine Anthropogenic Litter. - Springer International Publishing, Cham.

[5] Campbell, J., Barnett, J. (2010): Climate Change and Small Island States. - Routledge.

[6] Chae, Y., An, Y.-J. (2018): Current research trends on plastic pollution and ecological impacts on the soil ecosystem: A review. - Environmental Pollution 240: 387-395.

[7] Cheshire, A., Adler, E. (2009): UNEP/IOC Guidelines on Survey and Monitoring of Marine Litter. - United Nations Environment Programme (UNEP), Nairobi.

[8] Convey, P., Barnes, D., Morton, A. (2002): Debris accumulation on oceanic island shores of the Scotia Arc, Antarctica. - Polar Biology 25: 612-617.

[9] Eriksen, M., Lebreton, L. C. M., Carson, H. S., Thiel, M., Moore, C. J., Borerro, J. C., Galgani, F., Ryan, P. G., Reisser, J. (2014): Plastic Pollution in the World's Oceans: More 
than 5 Trillion Plastic Pieces Weighing over 250,000 Tons Afloat at Sea Dam, H.G. - PLoS ONE 9: e111913.

[10] Galgani, F., Leaute, J., Moguedet, P., Souplet, A., Verin, Y., Carpentier, A., Goraguer, H., Latrouite, D., Andral, B., Cadiou, Y., Mahe, J., Poulard, J., Nerisson, P. (2000): Litter on the Sea Floor Along European Coasts. - Marine Pollution Bulletin 40: 516-527.

[11] Galgani, F., Fleet, D., van Franeker, J., Katsanevakis, S., Maes, T., Mouat, J., Oosterbaan, L., Poitou, I., Hanke, G., Thompson, R., Amato, E., Birkun, A., Janssen, C. (2010): Marine Strategy Framework Directive: Task Group 10 Report Marine Litter. - Office for Official Publications of the European Communities, Luxembourg.

[12] Gall, S. C., Thompson, R. C. (2015): The impact of debris on marine life. - Marine Pollution Bulletin 92: 170-179.

[13] Goldstein, M. C., Goodwin, D. S. (2013): Gooseneck barnacles (Lepas spp.) ingest microplastic debris in the North Pacific Subtropical Gyre. - PeerJ 1: e184.

[14] Haynes, D. (1997): Marine debris on continental islands and sand cays in the Far Northern Section of the Great Barrier Reef Marine Park, Australia. - Marine Pollution Bulletin 34: 276-279.

[15] Hess, N. A., Ribic, C. A., Vining, I. (1999): Benthic Marine Debris, with an Emphasis on Fishery-Related Items, Surrounding Kodiak Island, Alaska, 1994-1996. - Marine Pollution Bulletin 38: 885-890.

[16] Hirai, H., Takada, H., Ogata, Y., Yamashita, R., Mizukawa, K., Saha, M., Kwan, C., Moore, C., Gray, H., Laursen, D., Zettler, E. R., Farrington, J. W., Reddy, C. M., Peacock, E. E., Ward, M. W. (2011): Organic micropollutants in marine plastics debris from the open ocean and remote and urban beaches. - Marine Pollution Bulletin 62: 1683-1692.

[17] International Coastal Cleanup (2009): Guide to marine debris and International Coastal Cleanup. - Ocean conservancy, Washiton.

[18] Ivar do Sul, J. A., Spengler, Â., Costa, M. F. (2009): Here, there and everywhere. Small plastic fragments and pellets on beaches of Fernando de Noronha (Equatorial Western Atlantic). - Marine Pollution Bulletin 58: 1236-1238.

[19] Kaikaew, S., Jitpraphai, S. M., Kettratad, J. (2018): Distribution of Plastic Marine Debris in Intertidal Zone at Sichang Island, Chonburi Province. - the 55th Kasetsart University Annual Conference: 19-26. Bangkok.

[20] Khananurux, N. (2012): Types and Sources of Marine debris in Bangsaen beach, Chonburi Province. $-\mathrm{PhD}$ thesis, Chulalongkorn University, Bangkok.

[21] Kühn, S., Bravo Rebolledo, E. L., van Franeker, J. A. (2015): Deleterious Effects of Litter on Marine Life. - In: Bergmann, M., Gutow, L., Klages, M. (eds.) Marine Anthropogenic Litter. Springer International Publishing, pp. 75-116.

[22] Kumar, A. A., Sivakumar, R., Reddy, Y. S. R., Raja, M. V. B., Nishanth, T., Revanth, V. (2016): Preliminary study on marine debris pollution along Marina beach, Chennai, India. - Regional Studies in Marine Science 5: 35-40.

[23] Lavers, J. L., Bond, A. L. (2017): Exceptional and rapid accumulation of anthropogenic debris on one of the world's most remote and pristine islands. - Proceedings of the National Academy of Sciences 114: 6052-6055.

[24] Lavers, J. L., Dicks, L., Dicks, M. R., Finger, A. (2019): Significant plastic accumulation on the Cocos (Keeling) Islands, Australia. - Scientific Reports 9: 7102.

[25] Leatherman, S. P., Beller-Simms, N. (1997): Sea-Level rise and small island states; an overview. - Journal of Coastal Research 24: 1-16.

[26] Lee, J., Hong, S., Lee, J. (2019): Rapid assessment of marine debris in coastal areas using a visual scoring indicator. - Marine Pollution Bulletin 149: 110552.

[27] Marin, C. B., Niero, H., Zinnke, I., Pellizzetti, M. A., Santos, P. H., Rudolf, A. C., Beltrão, M., de Souza Waltrick, D., Polette, M. (2019): Marine debris and pollution indexes on the beaches of Santa Catarina State, Brazil. - Regional Studies in Marine Science 31: 100771.

[28] Matsuoka, T., Nakashima, T., Nagasawa, N. (2005): A review of ghost fishing: scientific approaches to evaluation and solutions. - Fisheries Science 71: 691-702. 
[29] Nurse, L. A., Sem, G., Hay, J. E., Suarez, A. G., Wong, P. P., Briguglio, L., Ragoonaden, S. (2001): Small island states. - In: McCarthy, J. J., Canziani, O. F., Leary, N. A., Dokken, D. J., White, K. S. (eds.) Climate Change 2001: Impacts, Adaptation and Vulnerability.Contribution of Working Group II to the Third Assessment of the Intergovernmental Panel on Climate Change. Cambridge University Press, Cambridge.

[30] Plastics Europe (2016): Plastics- the Facts 2016: an Analysis of European Plastics. Plastics Europe, Brussels.

[31] Rangel-Buitrago, N., Williams, A., Anfuso, G. (2018): Killing the goose with the golden eggs: Litter effects on scenic quality of the Caribbean coast of Colombia. - Marine Pollution Bulletin 127: 22-38.

[32] Rayon-Viña, F., Miralles, L., Gómez-Agenjo, M., Dopico, E., Garcia-Vazquez, E. (2018): Marine litter in south Bay of Biscay: Local differences in beach littering are associated with citizen perception and awareness. - Marine Pollution Bulletin 131: 727-735.

[33] Ryan, P. G., Moore, C. J., van Franeker, J. A., Moloney, C. L. (2009): Monitoring the abundance of plastic debris in the marine environment. - Philosophical Transactions of the Royal Society B: Biological Sciences 364: 1999-2012.

[34] Sarafraz, J., Rajabizadeh, M., Kamrani, E. (2016): The preliminary assessment of abundance and composition of marine beach debris in the northern Persian Gulf, Bandar Abbas City, Iran. - Journal of the Marine Biological Association of the United Kingdom 96: 131-135.

[35] Scisciolo, T. de, Mijts, E. N., Becker, T., Eppinga, M. B. (2016): Beach debris on Aruba, Southern Caribbean: Attribution to local land-based and distal marine-based sources. Marine Pollution Bulletin 106: 49-57.

[36] Somerville, S., Miller, K., Mair, J. (2003): Assessment of the aesthetic quality of a selection of beaches in the Firth of Forth, Scotland. - Marine Pollution Bulletin 46: 1184-1190.

[37] Song, Y. K., Hong, S. H., Jang, M., Han, G. M., Jung, S. W., Shim, W. J. (2017): Combined Effects of UV Exposure Duration and Mechanical Abrasion on Microplastic Fragmentation by Polymer Type. - Environmental Science \& Technology 51: 4368-4376.

[38] Sutherland, W. J., Clout, M., Côté, I. M., Daszak, P., Depledge, M. H., Fellman, L., Fleishman, E., Garthwaite, R., Gibbons, D. W., Lurio, J. De, Impey, A. J., Lickorish, F., Lindenmayer, D., Madgwick, J., Margerison, C., Maynard, T., Peck, L. S., Pretty, J., Prior, S., Redford, K. H., Scharlemann, J. P. W., Spalding, M., Watkinson, A. R. (2010): A horizon scan of global conservation issues for 2010. - Trends in Ecology \& Evolution 25: $1-7$.

[39] Thammavichan, J., Manyagase, K., Manakij, J., Noomnual, W. (2014): Study of amount, material type and source of marine debris along the Andaman sea in Trang and Phuket province. - The 4th Marine Science Conference: 646-652.

[40] Tomás, J., Guitart, R., Mateo, R., Raga, J. A. (2002): Marine debris ingestion in loggerhead sea turtles, Caretta caretta, from the Western Mediterranean. - Marine Pollution Bulletin 44: 211-216.

[41] UNEP (2014): United Nations Environment Programme Year Book 2014: emerging issues in our global environment.

[42] Williams, A. T., Rangel-Buitrago, N., Pranzini, E., Anfuso, G. (2018): The management of coastal erosion. - Ocean \& Coastal Management 156: 4-20.

[43] Williams, A. T., Rangel-Buitrago, N. (2019): Marine Litter: Solutions for a Major Environmental Problem. - Journal of Coastal Research 35: 648-663.

[44] Wirachwong, P., Holmer, M. (2010): Nutrient dynamics in 3 morphological different tropical seagrasses and their sediments. - Aquatic Botany 93: 170-178.

[45] Wyles, K. J., Pahl, S., Thomas, K., Thompson, R. C. (2016): Factors That Can Undermine the Psychological Benefits of Coastal Environments. - Environment and Behavior 48: 1095-1126. 